\title{
Road kills in tropical ecosystems: a review with recommendations for mitigation and for new research
}

\author{
Julián Monge-Nájera \\ Laboratorio de Ecología Urbana, Vicerrectoría de Investigación, Universidad Estatal a Distancia, 2050 San José, Costa \\ Rica; julianmonge@gmail.com
}

Received 08-XII-2017. Corrected 02-II-2018. $\quad$ Accepted 12-II-2018.

\begin{abstract}
While roads are indispensable for modern civilization and beneficial for many wildlife species, they have been causing mortality from collisions since high speed chariots were invented 4000 years ago. Most scientific work about road kill has been done in temperate ecosystems, but some authors have suspected that they have different characteristics in tropical ecosystems. In this review, I summarize publications that focus on road kills in tropical countries from Africa, America, Asia and Oceania. I found 73 studies that focus on tropical road kills. Output increased after 2011 and the most productive countries, in articles per capita, are Costa Rica, Colombia and Brazil. Most studies report that mammals are the main victims, but bird deaths are severely underestimated and amphibians suffer mass mortality in reproductive concentrations. Every road victim is itself a small ecosystem that contains thousands of microscopic species, but "Road Kill Microbiology" is yet to be developed as a new branch of research. No generalization can be made about the role of season or habitat in road kills because pooled data hide individual trends: researchers should keep separate records by age, sex, species, time of day, season and place; otherwise important patterns will be missed. There is not a single study, tropical or temperate, that can completely answer how many animals are killed, where, or when, because many victims are removed by scavengers, end outside the road or are too small to be noticed. Significant contributions from the tropics include emphasis on the ethical use of road kill for research, inclusion of species other than wild vertebrates, study of often overlooked phenomena like hour of day and failed versus successful crossing attempts, and the value of speed control in mitigation. The so-called "citizen science" can identify the most affected species but produces data that are very different from those generated by professional scientists in terms of the proportion of affected groups. Real speed limitation is the simplest effective mitigation measure. Tropical scientists should concentrate on monitoring and experimental studies to fully understand the ecology of road kills and to make a contribution that matches what rich countries do. Rev. Biol. Trop. 66(2): 722-738. Epub 2018 June 01.
\end{abstract}

Key words: wildlife, vertebrate, collision, mortality, tropics, Road Kill Microbiology.

For millennia, roads have allowed the rise of civilizations and the communication of human societies. The global road network is the largest ever, and the current standard of living that humans enjoy would be impossible without it. Humans are not the only species benefited from roads, many other organisms use them for dispersal, and to find resources and mates. Nevertheless, roads also modify habitats and cause wildlife mortality, among several reasons, from collision with vehicles (Trombulak \& Frissell, 2000; Brown \& Brown,
2013; D’Anunciação, Lucas, Silva, \& Bager, 2013; Motley et al., 2016).

It may be thought, as Kroll (2015) did, that the problem of road kills began with the invention of the combustion engine and the "explosion" in the number of roads and automobiles in the early 20th century, but actually the problem has been recorded for thousands of years. Vehicles have been killing domestic animals and wildlife since high-speed chariots were invented more than 4000 years ago, even though few historians have cared to mention 
non-human victims of road accidents (Sanborn, 2008; Anthony, 2010; Kroll, 2015). The ancient Roman Stele of Edessa (Fig. 1) represents a pig killed by a vehicle and comments on the accident (Beard, 2015).

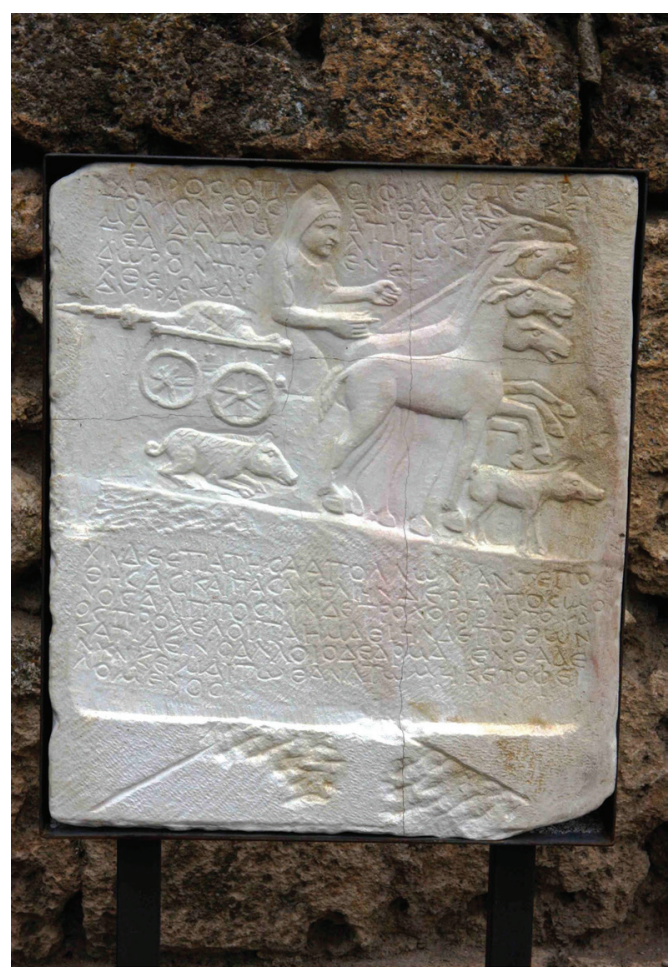

Fig. 1. Road kill in the Roman empire: the pig stele of Edessa, Macedonia; the text reads: "A pig, friend to everybody; a four-footed youngster; here I lie... But by the force of a wheel; I have now lost the light... Here now I lie, owing nothing to death anymore". Photograph by Philipp Pilhofer (Wikimedia.org)

From the point of view of conservation, the negative effects of roads on animal abundance outnumber positive effects by a factor of five, and merit routine mitigation (Fahrig \& Rytwinski, 2009). Most scientific work about road kills has been done in temperate ecosystems and the three basic findings can be summarized as follows:

Amphibians, reptiles, birds and mammals are the main vertebrate victims of collisions (the situation seems to be worse for large mammals).
Vultures -and some small birds and mammals- are often benefited by roads.

All vertebrate groups have species that seem to be unaffected by roads (either because they do not get close to roads or because they are able to escape from approaching vehicles).

Nevertheless, the problem is at least as serious in the tropics as in temperate regions. For example, extrapolation of data by the Centro Brasileiro de Estudos em Ecologia de Estradas estimated that 430000000 small vertebrates (mainly frogs, snakes and birds), 40000000 mid-size vertebrates (mainly monkeys, opossums), and 5000000 large vertebrates (mainly tapirs, and larger predatory canids and felids) become road kills in Brazilian roads every year (Guimarães, 2015).

Until now, no general review of road kills in the tropics had been published, but some particular groups have been reviewed (D'Anunciação, Lucas, Silva, \& Bager, 2013). Even though a couple of recent publications from Latin America did not mention any differences with temperate regions (Figueroa et al., 2014; De la Ossa, De la Ossa, \& Medina, 2015), some authors have predicted that differences will be found. For example, collisions with large-sized wildlife are a serious threat to human life in temperate countries but are rare in the tropics (Freitas, Sousa, \& Bueno, 2013); and more species are killed by collisions in the species-rich tropics, making conservation more urgent (Freitas, Sousa, \& Bueno, 2013).

In this review, I summarize publications that focus on road kills in tropical countries from Africa, America, Asia and Oceania, and compare them with reports from temperate countries.

\section{MATERIALS AND METHODS}

I searched Google Scholar, Web of Knowledge, Scopus, JSTOR, Springer Link, Science Direct, and Wiley Online Library, combining the search terms road kill; wildlife vehicle; collision; road; highway and traffic with the following words, that cover all countries with territory in the neotropics and paleotropics (for countries with parts outside the 
tropics, I also searched for the tropical states or provinces and excluded results from nontropical parts): Costa Rica, Mexico, Zacatecas, Tamaulipas, Nayarit, Aguas Calientes, San Luis Potosí, Guanajuato, Jalisco, Hidalgo, Colima, Michoacán, Querétaro, Tlaxcala, Morelos, Guerrero, Veracruz, Oaxaca, Tabasco, Chiapas, Quintana Roo, Yucatan, Campeche, Puebla, Belize, Honduras, Guatemala, El Salvador, Nicaragua, Costa Rica, Panamá, Colombia, Venezuela, Ecuador, French Guiana, Suriname, Peru, Bolivia, Brazil (Pará, Amapá, Mato Grosso, Manaus, Rio de Janeiro) Cuba, Haiti, Dominican Republic, Trinidad and Tobago, Puerto Rico, Nepal, Yemen, Oman, Somalia, Kenya, Thailand, India, Tanzania, Uganda, Ethiopia, Liberia, Namibia, Angola, Congo, Botswana, Chad, Nigeria, Malaysia, Indonesia, Bangladesh, Australia, Vietnam, Philippines, and Papua. Search dates: June through November, 2017.

I also included the number of records and main species in all the citizen science projects published in inaturalist.org as well as data and publications from the large citizen science project in Sistema Urubu, Brazil (http://cbee.ufla.br/portal/monografias). For comparison, I analyzed the data from a large temperate ecosystems project, California Roadkill Observation System, wildlifecrossing.net. The raw dataset is freely available online as Digital Appendix.

\section{RESULTS}

Formal studies: the search produced nearly 2000 results, but after discarding those that were not original studies focused on road kills from tropical ecosystems, only 73 studies remained for the analysis of this study. The works were from the American continent, Africa, Asia and Oceania, and here I present them in that geographic order, starting with Mexico.

Mexico: Despite its large economy and road network, Mexico has produced few studies about road kills and the design of "environmentally friendly roads" is in a very early stage (González \& Badillo, 2013). In Veracruz and Puebla the most common victims were Peromyscus rodents (González-Gallina, Benítez-Badillo, Rojas-Soto, \& HidalgoMihart, 2013). There is also a report of a large mammal, a female Tapirus bairdii, killed in Campeche, a paradoxical indication that the species -once thought extinct in the area- was still there (Contreras-Moreno, Hidalgo-Mihart, Pérez-Solano, \& Vázquez-Maldonado, 2013). Generally, Mexican authors have stressed the value of road kills as source of scientific data that can be obtained without additional sacrifice of wild organisms (González-Gallina, Benítez-Badillo, Hidalgo-Mihart, Equihua, \& Rojas-Soto, 2015).

Costa Rica: Unlike most studies that limit the concept of road kills to wildlife, an early study in Costa Rica included pets and found that cats and dogs are the most frequent victims. Among wildlife species, the opossum Didelphis marsupialis and the anteater Tamandua mexicana dominate road kill numbers. Mammals suffered more casualties (both in individuals and as species), followed by birds and reptiles; amphibians were rarely recorded (Monge-Nájera, 1996). Almost no studies compare casualties with the actual number of animals crossing roads, but this study reports that birds were four times more likely to survive encounters with cars than mammals; it also included invertebrates and found that thousands of pierid butterflies, Eurema sp., become road kills during migration (Monge-Nájera, 1996).

In a secondary road, frogs (Bufonidae) were the main victims (amphibians are generally reported to be rare among road kills, with exceptions, see Vijayakumar, Vasudevan \& Ishwar, 2001; Arévalo, Honda, Arce-Arias \& Häger, 2017) and that at higher traffic levels, less animals crossed and died, possibly because they were frightened by the heavy traffic (Rojas-Chacón, 2011). Compared to a gravel road, a paved road had more traffic and more deaths, but less individuals and species of mammals approached it. The jaguar, Panthera onca, and the margay, Leopardus wiedii, were 
seen crossing but did not become road kills; and raccoons, Procyon lotor, frequently used a culvert as underpass (Araya-Gamboa \& SalomPérez, 2015).

In a Caribbean road, opossums (D. marsupialis), armadillos (Dasypus novemcinctus) and four-eyed opossums (Philander opossum) were the most frequent victims (Artavia et al., 2015). With one exception, the same species led road kill lists in the northern part of the country: $D$. marsupialis, T. mexicana and D. novemcinctus (Alfaro \& Quesada, 2016). An even more recent study is particularly important because it found mass mortality of frogs during the reproductive season (Arévalo et al., 2017).

Colombia: Colombia is among the Latin American leaders in the study of road kills. A decade ago, in Antioquia, marsupials, rodents and predators, including the endangered felids Leopardus tigrinus, Puma yagouaroundi, and the recently discovered procyonid Bassaricyon neblina, were the most common mammal victims. The author of the study recommended education and road signs to mitigate the problem (Delgado-Vélez, 2007; 2014).

More recently, an experiment with marked marsupials (Marmosa robinsoni) and rodents (Melanomys caliginosus, Handleyomys alfaroi, Rhipidomys latimanus and Heteromys australis) found that the animals avoid crossing roads in Yotoco (Vargas-Salinas \& LópezAranda, 2012).

In the Magdalena river region, mammals and reptiles were the prevalent victims by both individuals and biomass, while birds followed in number of species and -like in other tropical studies- anurans were rare. The four most frequent victims were $T$. mexicana, D. marsupialis, crab-eating foxes (Cerdocyon thous) and boas (Boa constrictor). Deaths were not associated with home range, number of safe crossing structures available, or rivers (DiazPulido \& Benítez, 2013).

In northern Colombia, more animals died in the dry season, particularly D. marsupialis, the frog Rhinella marina, the vulture Coragyps atratus and the bird Pitangus sulphuratus. A second study in the same area, two years later, reported again $R$. marina, but found instead other species as the main victims: the snake Leptodeira septentrionalis) and the opossum D. marsupialis (Nadjar \& De la Ossa, 2013; La Ossa-Nadjar \& De La Ossa, 2015). This difference reflects the complexity of the situation in the tropics.

In Sucre, Colombian Caribbean, the most frequent victims were mammals, birds, reptiles and amphibians in similar proportions, particularly the fox $C$. thous $(10.9 \%)$, iguanas (Iguana iguana) and the bird Crotophaga ani. Traffic and species behavior seemed to be the main causes of mortality (De La Ossa \& Galván-Guevara, 2015). In Quindío, a study did not find evidence that biological corridors reduced mortality, a problem that has been found in many temperate and tropical areas (López-Herrera, León-Yusti, Guevara-Molina, \& Vargas-Salinas, 2016).

Venezuela: In the road between Caracas and Mantecal, the main victim was the caiman, Caiman crocodilus, followed by D. marsupialis and $C$. thous, at least during the rainy season (Pinowski, 2005). In Portuguesa, the most frequent victims were the snake Leptodeira annulata, the opossum D. marsupialis, and the crocodyle $C$. crocodilus. Overall, reptiles, mammals and birds were more common, and historically, heavier traffic meant more road kills (Eloy Seijas, Araujo-Quintero, \& Velásquez, 2013).

Andes: Four studies report on the Andean highlands of South America, two from Colombia, one from Ecuador and one from Bolivia. In the Colombian Andes, snake counts were unusually high, particularly Atractus cf melanogaster and Liophis epinephelus (QuinteroÁngel, Osorio-Dominguez, Vargas-Salinas, \& Saavedra-Rodríguez, 2012). In Ecuador, the most frequent Andean victims were mammals, birds and reptiles. For most species, road kills were more frequent near cattle farms, and for amphibians, near water (Medrano, 2015). In Bolivia, a detailed study of snake mortality 
in the highlands found that $18 \%$ of victims belong to endemic species; that males die in higher numbers than females; that terrestrial snakes dominate the counts (over species associated with water, trees and the underground); and that less snakes die during the dry season (Sosa \& Schalk, 2016).

Brazil and French Guiana: Brazil produces a large number of articles and has some of the most detailed studies about the relationship between environmental characteristics and number of animals killed. In Carajás, the main victims were snakes, opossums (D. marsupialis) and birds; and -unlike other studies- rain had no effect and victim counts diminished from 2003 to 2006 (Gumier-Costa \& Sperber, 2009). In the road between Goiânia and Iporá, most victims were mammals (Tamandua tetradactyla, C. thous and Myrmecophaga tridactyla), with only a small proportion of birds, and even less reptiles. Large and small mammals died in similar numbers, and there were no strong seasonal changes or clear effects of vegetation (Ferreira da Cunha, Alves Moreira, \& Sousa Silva, 2010)

For small species, counts from vehicles severely underestimate deaths, so the study of Coehlo et al. (2012) used foot surveys. They found that water and artificial lights become "ecological traps" that cause high anuran mortality. But this mortality concentrates on predictable "hotspots" that vary with the species, i.e. traffic bans during the reproductive season would be effective to greatly reduce anuran mortality (Coehlo et al., 2012).

In southern Brazil, bird casualties concentrated near rice fields and wetlands, with more species and deaths in summer and autumn. A small scale, nearby areas had similar kill rates, independent of habitat, perhaps because animals died when attracted to grain fallen from trucks (da Rosa \& Bager, 2012). In the Atlantic mountains, victims are mainly mammals, followed by birds and reptiles. While most dead birds did not show a clear relation with landscape features, the following died in greater numbers near higher herbaceous vegetation: reptiles, owls, large mammals, and arboreal mammals. All species suffered more losses near rivers (Freitas, Sousa, \& Bueno, 2013).

One of the most significant papers published anywhere about road kills is a study by Teixeira, Coelho, Esperandio and Kindel (2013), because it addresses a central problem in road kill ecology: mortality is usually underestimated because carcasses are removed by scavengers, or are undetected by researchers for a variety of reasons. Using mathematical modeling, Teixeira et al. (2013) found that the number of specimens seen must by multiplied by a correcting factor according to group, 20 times for birds, 5 times for reptiles, and 2 times for small mammals (Teixeira et al., 2013).

In Mato Grosso do Sul, main victims were the bird Cariama cristata and the fox C. thous. The sections of highway closest to cities had more deaths, particularly near dense vegetation (Carvalho, Bordignon, \& Shapiro, 2014). In Minas Gerais, most victims were mammals, birds and reptiles, and unexpectedly, no more animals died on paved than on unpaved roads (Machado, Fontes, Moura, Mendes, \& Romao, 2015).

In Chapada dos Veadeiros the most frequent victims were Schneider's toad (Rhinella schneideri), the grassland sparrow (Ammodramus humeralis), and the yellow-toothed cavy (Galea flavidens). There were more deaths in the wet season. More amphibians died near forests, while reptiles and birds died mostly near open vegetation. Mammals died more on unpaved roads (Braz \& França, 2016).

In the Amazon-Cerrado transition, reptiles, amphibians and birds were infrequent victims, while mammals were common. In humanimpacted habitat, a frequent victim was $C$. thous and the armadillo Euphractus sexcinctus, whereas the anteater M. tridactyla and C. thous led the list in protected land (Brum, SantosFilho, Canale, \& Ignácio, 2017).

There is a single report from French Guiana, where T. tetradactyla is the most common road kill victim (Catzeflis \& Thoisy, 2012).

Brazil has also contributed an important number of articles on methods and other 
practical problems of road kill ecology. As expected, hot spots (i.e. sections of roads where most killing occurs) depend on the species (Teixeira, Coelho, Esperandio, Oliveira, \& Porto, 2013), but their existence also facilitates mitigation, because work on those road sections has a large positive impact, particularly if done with the participation of local communities (Dougherty, 2015). Brazilian scientists have also answered key questions, like how often and for how long do we need to count kills; what correction factors must be used when counting small animals; how much money can be saved with mitigation; and how to make decisions about mitigation more objective.

To obtain a reliable and detailed image of road kill deaths, sampling weekly for at least two years is a good rule, at least for the neotropical species studied in Brazil (Bager \& Rosa, 2011; Costa Ascencão, \& Bager, 2015; Santos et al. 2017).

Most vertebrate victims are small, with a body mass under $500 \mathrm{~g}$, and in many cases under $100 \mathrm{~g}$, which greatly reduces their chance of being detected because they are rapidly removed by scavengers and because they can only be detected by walking observers (Santos, Rosa, \& Bager, 2012; Santos et al., 2016).

Besides the death of wild animals, and even when humans are not hurt, vehicle repair has a cost than may be higher than the cost of mitigation. For example, for capybaras (Hydrochoerus hydrochaeris), in road sections where more than five animals are killed each year, car repair costs are higher than the cost of installing fences and culverts (Huijser, Abra, \& Duffield, 2013).

Mitigation measures are often recommended by researchers without real data about their effectiveness (D'Anunciação et al., 2013), and the few results from the tropics leave little space for optimism (Bager \& Fontoura, 2013; Ciocheti, Assis, Ribeiro, \& Ribeiro, 2017). A reasonalbe approach is to concentrate mitigation on endangered species and road segments with high mortality as proposed by Bager and Rosa (2010).
Finally, a particularly interesting result from Brazil is the study by Secco, Ratton, Castro, Lucas and Bager (2014) who found that some drivers intentionally run over snakes, but unlike drivers in Australia, Canada or the USA, Brazilian drivers run over control objects with equal speed and frequency. They also found that the behavior is worst among truck drivers, who are less afraid of damage to their vehicles (Secco, et al., 2014).

Africa: African studies have been made in Madagascar, and more recently in Tanzania, Uganda and Ethiopia. A study in Madagascar is of particular interest because it found that construction of two speed bumps significantly reduced deaths for all vertebrate groups along the entire road, suggesting that speed bumps also act as psychological deterrent (Schutt, 2008).

A study in Tanzania found that birds were the most frequent victims, followed by mammals and reptiles (like almost everywhere else, amphibians were rare; but this might be an artifact, see Arévalo, et al., 2017). Mortality was higher near nature reserves, and -excluding birds- nocturnal species suffered more (Kioko, Kiffner, Jenkins, \& Collinson, 2015). Just like in Mexico (González-Gallina, et al. 2015), a report from Uganda highlighted that road victims can be used to assess the health status of wildlife without directly affecting their populations, and recommended speed-bumps to reduce risks to wildlife and human pedestrians (McLennan \& Asiimwe, 2016).

Mammals and birds had the highest species richness among victims in Ethiopia, where most accidents happened during the early morning and late evening, possibly from a combination of reduced visibility and higher animal and vehicle traffic (Kiros et al., 2016).

Asia: By number of articles, the study of road kills in tropical countries of Asia follows the Neotropics and comes mainly from India, Sri Lanka and Malaysia.

A study of reptiles and mammals in India found more dead reptiles at night and during the rainy season, leading to the recommendation of 
reducing tourism pressure in critical periods and areas, particularly because some of the victims were members of endangered species (Kumara, Sharma, Kumar, \& Singh, 2000). In the Anamalai Hills, amphibians and uropeltid snakes were the main victims, with more deaths during rainy periods; road kills threatened their conservation because of the scarcity of herpetofauna in rainforests (Vijayakumar, Vasudevan, \& Ishwar, 2001).

More recent work from India has been done in nature reserves and Bhavnagar city. Reptiles were the most affected in Bandipur, followed by amphibians and mammals, especially during the pre-monsoon (Selvan, Sridharan, \& John, 2012). The monsoon seems to increase the mortality of snakes in hotspots that occur mainly in the highlands, far from agriculture fields, animals crossings and water sources (Pragatheesh \& Rajvanshi, 2013). In the Durrah and Ramgarh, snakes and lizards were the main reptilian victims, and even though the number was small (a mean of two per month) the cumulative effect was significant for rare species (Nagar, Meena, \& Dube, 2013). A similar result was found in Mudumalai: reptiles were the most affected vertebrates, followed by mammals (Samson et al., 2016).

A study in Bhavnagar found a similar pattern of reptiles and mammals dominating the list, while amphibians were rare. Just like in nature reserves, threatened and vulnerable species appeared among the victims, e.g. the striped hyena (Hyaena hyaena); red sand boa
(Eryx johnii) and Indian softshell turtle (Nilssonia gangetica), with more deaths when rains were intermittent and animals had to travel in search of water (Solanki, Beleem, Kanejiya, \& Gohil, 2017).

Closer to the equator, in Sri Lanka, herpetofauna were also reported as the main victims in nature reserves, particularly during the night and in the high tourist season, making a restriction of speed and visitation the key mitigation measures (Karunarathna, Ranwala, Surasinghe, \& Madawala, 2017).

Oceania: Most roads and highways in Oceania remain unstudied. In the case of Australia, work concentrates in temperate parts. In tropical Australia, the most frequently killed native species are the northern brown bandicoot (Isoodon macrourus), the mountain brushtail possum (Trichosurus cunninghami) and the Australian magpie (Cracticus tibicen) (Taylor \& Goldingay, 2004). A study in the Palmerston Highway found no evidence that overpasses were useful to reduce losses of the Ringtail Possum, Pseudochirulus herbertensis (Goosem, Wilson, Weston, \& Cohen, 2008).

General trends: The number of articles about tropical road kills increased after 2011 but is still small (Fig. 2). The most productive countries by total articles are Colombia, Brazil, Costa Rica, India and Mexico (Fig. 3), but correcting for population size, the leaders are Costa Rica (1.25 articles per

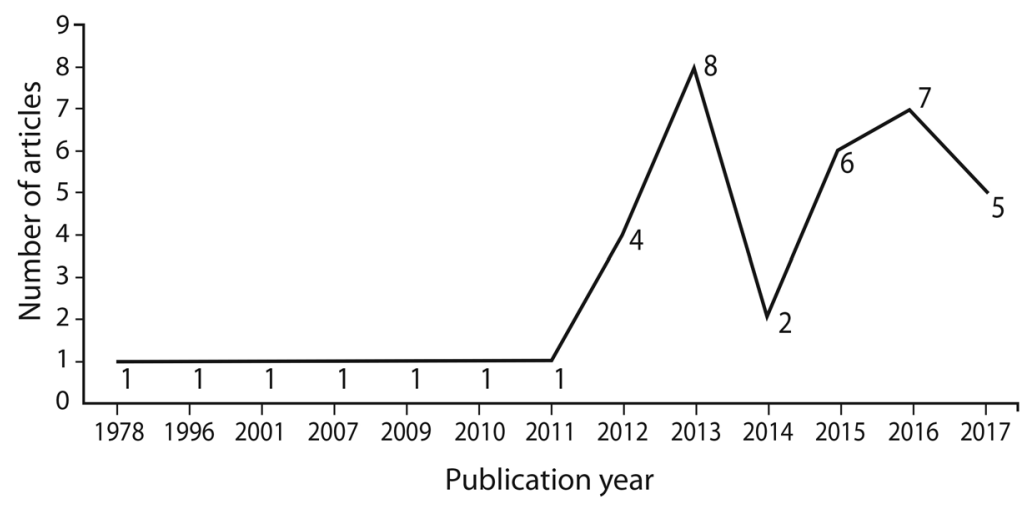

Fig. 2. Historical trend in the production of scientific articles about road kills in tropical ecosystems. 


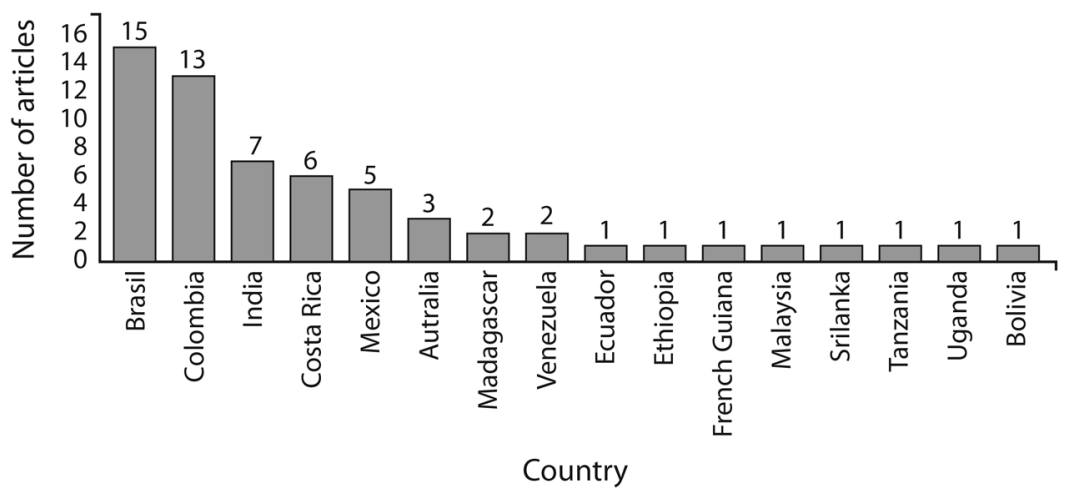

Fig. 3. Number of articles about road kills in tropical ecosystems, by country.

million inhabitants), Colombia (0.27 articles per million inhabitants) and Brazil (0.05 articles per million inhabitants).

Once corrected, birds dominate, and are followed by amphibians, reptiles and mammals (Fig. 4 and Digital Appendix 1). These results are based on studies done from automobiles, they do not include the more reliable results about anurans based on foot counts (Teixeira et al., 2013; Arévalo et al., 2017), which fall well within the corrected values.

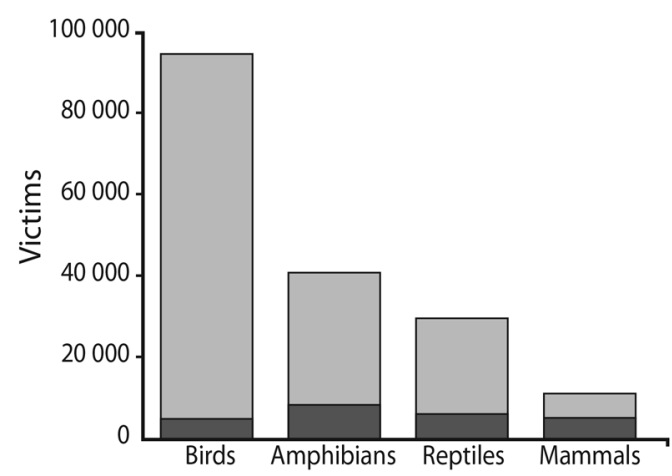

Fig. 4. Vertebrate groups by total cumulative number of victims reported in the literature about road kills in tropical ecosystems (dark blue). The lighter part of the bars correspond to the estimated real number of deaths, corrected according to Teixeira et al. (2013), by multiplying by 20 times for birds, 5 times for reptiles, and approximately 2 times for small mammals (Teixeira et al., 2013: equation 4 in page 318 and Table 2 in page 321; they do not provide a correction factor for amphibians, but I applied the reptilian value considering that amphibians have a similar size).
Citizen science: Besides scientists, some non professionals have developed an interest in road kills, from dolls inspired in them and sold by a London company named Road Kill Toys (roadkilltoys.com) to their use in food and art (Peterson, 1987; Parry, 2007), and this interest could be harnessed for research and mitigation, but work along this line has hardly started. The development of smartphone applications that allow distance insertion of images and data to servers, led to the establishment of road kill databases that can be used to identify sites and species in need of protection. These "citizen science" databases normally include time, date, location and photograph of the road kill, and a network members who can help in the identification of the species.

A dozen road kill databases were available in iNaturalist at the time of the search, and the second largest is tropical: Fauna Silvestre en Carreteras de Costa Rica, with 939 reports, mainly tamanduas, opossums and raccoons. The other large databases were the Adventure Scientists Wildlife Connectivity Survey (USA) with 9030 records led by raccoons, opossums and gopher snakes; and the Vashon-Maury Road Kill (Washington State, USA) with 771 records led by the Rough-skinned Newt, Golden-crowned Kinglet and Song Sparrow.

For comparison, data from the scientific literature and the largest temperate and tropical citizen science projects appear in Table 1. The proportions from citizen science projects are different between tropical and temperate sites, 
TABLE 1

Percentage of road kill victims by vertebrate group, based on large samples

\begin{tabular}{lccc} 
Vertebrate group & $\begin{array}{c}\text { Scientific articles } \\
\text { (Digital Appendix 1) }\end{array}$ & $\begin{array}{c}\text { Temperate Database } \\
\text { (wildlifecrossing.net) }\end{array}$ & $\begin{array}{c}\text { Tropical Database } \\
\text { (cbee.ufla.br) }\end{array}$ \\
Amphibians & 34 & 2 & 8 \\
Reptiles & 25 & 5 & 19 \\
Birds & 20 & 12 & 20 \\
Mammals & 21 & 81 & 53 \\
\hline
\end{tabular}

and these in turn are very different from scientific reports. Around half of the reports from the citizen science tropical database are from mammals, and amphibians are the smallest group. In the temperate citizen science database, most data are from mammals, and other groups represent less than $20 \%$ in total. By contrast, data from the scientific literature are nearly equally divided among all groups, with a slight dominance by amphibians (Table 1).

Proportions calculated from 23791 victims added from reports from the scientific literature (Digital Appendix 1; without correction for detectability); 53678 from the US citizen science project, and 19113 from the Brazil citizen science project.

\section{DISCUSSION}

Every day, millions of animals become road kill in tropical countries, and even though these countries have less resources for their study, they have made significant contributions in the ethical use of road kills for research, inclusion of species other than wild vertebrates, study of often overlooked phenomena like hour of day and failed versus successful crossing attempts, and the value of speed control in mitigation. Every road kill victim is a small ecosystem in itself, with millions of microorganisms and cells that could be studied for parasitic infections, health status, reproductive periods and a myriad other aspects (GonzálezGallina, Benítez-Badillo, Hidalgo-Mihart, et al., 2015; McLennan \& Asiimwe, 2016; Motley et al., 2016). Bacteria and other microorganisms (fungi, viruses) are carried alive in tissue bits to new habitats when tires contact remains on the road (Francisco Hernández, personal communication, 2017), an aspect that has never been studied and that hopefully will open a totally new research field in the future: Road Kill Microbiology.

While researchers in temperate countries normally limit themselves to wildlife, some tropical researchers have taken a more complete approach by including urban organisms, including pets and even humans, which also are road kill victims, as well as insects and other invertebrates (and seeds), which die in even greater numbers, thus enriching our knowledge of the problem (Monge-Nájera, 1996; McLennan \& Asiimwe, 2016). Emphasis on the observation that merging data from different times of day hides important trends is also part of the valuable tropical contributions (Kumara et al, 2000; Kioko, Kiffner, Jenkins, \& Collinson, 2015; Kiros et al., 2016; Karunarathna, Ranwala, Surasinghe \& Madawala, 2017). There are no studies of why birds are common victims in Africa and some parts of South America, but rare elsewhere, but apparently the only quantification of their car avoiding success rate is also tropical (Monge-Nájera, 1996).

Tropical researchers have also raised the alarm on the small effect that safe-crossing structures may have (Goosem et al., 2008; Díaz-Pulido \& Benítez, 2013; López-Herrera et al., 2016) and emphasized the greater value of actually reducing speed, a measure with satisfactory results in Madagascar, where speed bumps were tested (Schutt, 2008) and in Tikal, Guatemala, where vehicles are recorded by officers at the beginning and end of the road to 
guarantee enforcement of speed limits (personal observation, 2012).

No overall generalization can be made about the role of season or habitat in road kills because data are different from one study to another, reflecting the complexity of the phenomenon and possibly also methodological limitations. For example, some authors have reported that habitat along the road has no effect on road kills (e.g. Ferreira de Cunha et al., 2010; da Rosa \& Bager, 2012; Freitas, Sousa \& Bueno, 2013); while others have found that more animals die if the road is close to water (Arévalo et al. 2017), open vegetation (e.g. Medrano Viscaino, 2015) or, depending on the species, forest (Monge-Nájera, 1996; Braz \& Franca, 2016; Brum et al., 2017). In similar terms, higher mortalities have been recorded in rainy periods (Viiayakumar et al., 2001) and dry periods (Nadjar \& De la Ossa, 2013), while others have found no association (Gumier-Costa \& Sperber, 2009). For such a complex phenomenon, data should rarely be merged: the patterns appear to be quite specific for age, sex, species, time of day, season and place (Knutson, 1986; Monge-Nájera, 1996; Machado, Fontes, Moura, et al., 2015; Braz \& Franca, 2016).

Additionally, countries with reasonable scientific resources and large road infrastructure in tropical areas, like Australia, Mexico and India (Goosem, Wilson, Weston et al., 2008; González-Gallina, Benítez-Badillo, HidalgoMihart, et al., 2015; Karunarathna, Ranwala, Surasinghe et al., 2017), should have a larger output of articles about road kill and its mitigation: they have much work ahead.

The finding of only 73 tropical studies may be considered small, but it is not far from the 79 found by Fahrig and Rytwinski (2009) for their review of all articles about traffic and animal abundance worldwide. The formal study of road kills began a century ago but is still in its infancy, and despite the larger number of studies done in temperate regions, our knowledge of the problem is poor because of methodological problems, both in temperate and tropical ecosystems. The first problem is that we cannot answer with precision questions such as which organisms are killed, where or when. Indeed we have estimates, but not the actual numbers, and the reason is that many road kills are not visible to researchers because scavengers rapidly remove them, because the corpses end outside the road, because they cannot be identified, or because they are too small to be noticed (Monge-Nájera, 1996; Antworth, Pike, \& Stevens, 2005). Unfortunately, as I corroborated during the preparation of this review, some authors fail to follow the advice of Antworth et al. (2005) about limiting conclusions according to the weaknesses of data.

The second problem relates to mitigation: even if the real number of victims were known, we would still ignore if they represented a significant proportion of the population, because the real size of animal populations is mostly unknown and is always changing. In any case, small mitigation measures like underpasses and buffer zones appear to be of little help, and with few mortality studies "before" and "after" the installation of wildlife-crossing structures, their efficiency is hard to evaluate (Spellerberg, 1998; Trombulak \& Frissell, 2000; Glista, DeVault, \& DeWoody, 2009).

However, before-and-after comparisons can also be unreliable, because changes may be caused by factors unrelated to road kills (Goosem, M., Wilson, R., Weston, et al., 2008; González-Gallina, A., Benítez-Badillo, G., Hidalgo-Mihart, et al. 2015). For example, a decrease in the number of victims after the installation of crossing structures can indeed indicate that the structures are successful; but other causes are possible: the animals may simply have learned to avoid vehicles; may have moved elsewhere; or may be falling in numbers for a myriad other reasons like parasites and food shortages (Ranta, Lundberg, \& Kaitala, 2006).

To obtain better road kill data, Trombulak and Frissell (2000) urged experimental research to complement post-hoc correlative studies, but there are ethical difficulties in any experimentation with real animals, and studies with fake victims have limited application 
(Ashley, Kosloski, \& Petrie, 2007); to my knowledge, no one has used fake animals to study the reactions of wildlife but it is reasonable to think that vultures and other visually oriented scavengers and predators could react just like humans do. Better results need double blind experiments, together with treatment and control groups, as done in medical research (see Schulz, Chalmers, Hayes, \& Altman, 1995), but apparently, such studies have not been attempted in road kill ecology.

Until new methods allow better answers, we should assume that animals need protection (Fahrig \& Rytwinski, 2009). Road-free areas are an extreme but expensive solution (Goosem, 2007; Fahrig \& Rytwinski, 2009) and Knutson (1986) remarked that, since road kills affect animal populations, natural selection must be operating on them and leading to adaptation, which seems to be the case as suggested by ethological and morphological adaptations (Laurian et al., 2008; Rojas-Chacón, 2011; Vargas-Salinas \& López-Aranda, 2012; Brown \& Brown, 2013).

Like the previous temperate-tropical comparison done by D'Anunciação et al. (2013), who compared both results and methods, I did not find any remarkable differences in road kill between tropical and temperate habitats, but earlier suggestions that tropical species are more vulnerable and that collisions with large mammals are less frequent (Laurance, Goosem, \& Laurance 2009; Freitas, Sousa, \& Bueno, 2013) might be true; we need data to test such hypotheses. Additionally, the little effect of road kill on bird populations found by Bager and Rosa (2012) caused by the relative scarcity of any particular tropical species, deserves special attention by future workers.

The finding that citizen science projects present vertebrate group distributions that are very different from those of the scientific literature is worrisome: I strongly recommend comparative studies to check if this means that citizen science data are too biased to be useful for anything but the identification of hotspots and conspicuous victims.
To make a significant contribution to science and put tropical researchers ahead of merely observational research done elsewhere, I recommendations long term monitoring plans, and experimentation: monitoring to determine what portion of the population is lost to roads, and double blind experiments, with proper treatments and controls, to identify correctly the causes of road kill patterns. The key condition? A stringent respect for ethical guidelines: after all, other animals suffer as much as we do in road accidents.

\section{ACKNOWLEDGMENTS}

I thank Carolina Seas for her assistance with data collection and processing; Sergio Aguilar for the figures; Federico Bolaños and Daniel Briceño for suggesting the review; and Edgardo Arévalo-Hernández and three anonymous reviewers for valuable suggestions to improve the manuscript.

\section{RESUMEN}

Mortalidad en carreteras de ecosistemas tropicales: revisión con recomendaciones para su mitigación e investigación futura. Si bien los caminos son indispensables para la civilización moderna y benefician a muchas especies de vida silvestre, han estado causando mortalidad por atropello desde que se inventaron los carruajes de alta velocidad hace 4000 años. La mayoría de trabajos científicos en el tema se han realizado en ecosistemas templados, pero algunos autores han sospechado que hay diferencias en ecosistemas tropicales. En esta revisión, resumo publicaciones que se centran en muertes en carretera en países tropicales de África, América, Asia y Oceanía. Encontré 73 estudios pertinentes. El número de artículos aumentó después del 2011 y los países más productivos, en artículos per capita son Costa Rica, Colombia y Brasil. En muchos estudios, los mamíferos aparecen como víctimas más frecuentes, pero los anfibios sufren mortalidad masiva durante la época reproductiva y la mortalidad de aves es unas 20 veces mayor de lo que se creía. Cada víctima es un pequeño ecosistema en sí, lleno de especies microscópicas, pero la microbiología de fauna atropellada aún no se desarrolla como rama nueva de la ciencia. No se puede generalizar sobre el papel de la temporada o el hábitat en la mortalidad en carreteras porque los datos mezclados ocultan patrones individuales. Para evitar conclusiones erróneas, hay que mantener registros separados por año, sexo, especie, hora del día, época y lugar. Muchas víctimas son movidas 
por los carroñeros, mueren fuera de la carretera, o son demasiado pequeñas para ser notadas, por lo que no hay un solo estudio, tropical o templado, que pueda responder con certeza y precisión cuántos animales mueren, dónde o cuándo: sólo tenemos aproximaciones. Las contribuciones importantes de los estudios tropicales incluyen el énfasis ético en aprovechar los especímenes atropellados para investigación, la inclusión de especies que no son de vida silvestre, el estudio de aspectos poco entendidos (como el efecto de la hora del día y tasas de éxito y fracaso al cruzar la carretera, así como la eficacia comprobada de reducir la velocidad para mitigar el problema). La llamada "ciencia ciudadana" puede identificar las especies más afectadas, pero aporta datos muy diferentes de los generados por científicos profesionales en cuanto a proporción de grupos afectados. La reducción de velocidad es la medida de mitigación más simple y efectiva. Respetando directrices éticas, los científicos tropicales deberían concentrarse en el monitoreo conservacionista, y en el trabajo experimental para entender mejor la ecología de los atropellos y hacer un aporte que compita con el de los países ricos.

Palabras clave: vida silvestre, vertebrados, atropellos, mortalidad, trópico, microbiología de fauna atropellada.

\section{REFERENCES}

Alfaro, V. C., \& Quesada, F. D. (2016). Registro de mamíferos silvestres atropellados y hábitat asociados en el cantón de La Fortuna, San Carlos, Costa Rica. Biocenosis, 30(1-2), 49-58.

Anthony, D. W. (2010). The Horse, the Wheel, and Language: How Bronze-Age Riders from the Eurasian Steppes Shaped the Modern World Princeton. New Jersey, USA: Princeton University.

Antworth, R. L., Pike, D. A., \& Stevens, E. E. (2005). Hit and run: effects of scavenging on estimates of road killed vertebrates. Southeastern Naturalist, 4(4), 647 656. doi:10.1656/1528-7092(2005)004[0647:HARE OS]2.0.CO;2

Araya-Gamboa, D., \& Salom-Pérez, R. (2015). Método para la identificación de pasos de fauna sobre la Ruta 415, dentro del Subcorredor Biológico BarbillaDestierro "Paso del Jaguar", Costa Rica. San José, Costa Rica: Panthera Costa Rica.

Arévalo, J. E., Honda, W, Arce-Arias, A., \& Häger, A. (2017). Spatiotemporal variation of road kills show mass mortality events for amphibians in a highly trafficked road adjacent to a national park, Costa Rica. Revista de Biología Tropical (in press).

Artavia, A., Jiménez, M., Martínez-Salinas, A., Pomareda, E., Araya-Gamboa, D., \& Arévalo-Huezo, E. (2015). Registro de mamíferos silvestres en la sección de la ampliación de la Ruta 32, Limón, Costa Rica. Brenesia, 83-84, 37-46
Ashley, E., Kosloski, A., \& Petrie, S. A. (2007). Incidence of intentional vehicle-reptile collisions. Human Dimensions of Wildlife, 12(3), 137-143. doi:10.1080/10871200701322423

Bager, A., \& Fontoura, V. (2013). Evaluation of the effectiveness of a wildlife roadkill mitigation system in wetland habitat. Ecological Engineering, 53, 31-38.

Bager, A., \& Rosa, C. A. (2012). Impacto da rodovia BR-392 sobre comunidades de aves no extremo sul do Brasil. Revista Brasileira de Ornitologia, 20(1), 30-39.

Bager, A., \& Rosa, C. A. D. (2010). Priority ranking of road sites for mitigating wildlife roadkill. Biota Neotropica, 10(4), 149-153.

Beard, M. (2015). The pig's epitaph. The Times Literary Supplement. Retrieved from http://timesonline.typepad.com/dons_life/2015/03/the-pigs-epitaph.html

Braz, V. D. S., \& França, F. G. R. (2016). Wild vertebrate road kill in the Chapada dos Veadeiros National Park, Central Brazil. Biota Neotropica, 16(1), e0182. doi:10.1590/1676-0611-BN-2014-0182

Brown, C. R., \& Brown, M. B. (2013). Where has all the road kill gone? Current Biology, 23(6), R233-R234.

Brum, T. R., Santos-Filho, M., Canale, G. R., \& Ignácio, A. R. A. (2017). Effects of roads on the vertebrates diversity of the Indigenous Territory Paresi and its surrounding. Brazilian Journal of Biology, Epub June 12, 2017. doi: 10.1590/1519-6984.08116

Carvalho, N. C. D., Bordignon, M. O., \& Shapiro, J. T. (2014). Fast and furious: a look at the death of animals on the highway MS-080, Southwestern Brazil. Iheringia. SérieZoologia, 104(1), 43-49. doi:10.1590/1678-4766201410414349

Catzeflis, F., \& Thoisy, B. D. (2012). Xenarthrans in French Guiana: a brief overview of their distribution and conservation status. Edentata, 13, 29-37. doi: $10.5537 / 020.013 .0116$

Ciocheti, G., Assis, J. C., Ribeiro, J. W., \& Ribeiro, M. C. (2017). Highway widening and underpass effects on vertebrate road mortality. Biotropica, 49, 765-769. doi:10.1111/btp. 12480

Coelho, I. P., Teixeira, F. Z., Colombo, P., Coelho, A. V. P., \& Kindel, A. (2012). Anuran road-kills neighboring a peri-urban reserve in the Atlantic Forest, Brazil. Journal of Environmental Management, 112, 17-26.

Contreras-Moreno, F. M., Hidalgo-Mihart, M. G., PérezSolano, L. A., \& Vázquez-Maldonado, Y. A. (2013). Nuevo registro de Tapir centroamericano (Tapirus bairdii) atropellado en el Noroeste del estado de Campeche, México. Tapir Conservation, 22(30), 22-25. 
Costa, A. S., Ascensão, F., \& Bager, A. (2015). Mixed sampling protocols improve the cost-effectiveness of roadkill surveys. Biodiversity and Conservation, 24(12), 2953-2965.

D’Anunciação, P. E. R., Lucas, P. S., Silva, V. X., \& Bager, A. (2013). Road ecology and Neotropical amphibians: contributions for future studies. Acta Herpetologica, 8(2), 129-140.

da Rosa, C. A., \& Bager, A. (2012). Seasonality and habitat types affect road kill of neotropical birds. Journal of Environmental Management, 97, 1-5. doi:10.1016/j. jenvman.2011.11.004

De La Ossa, J., \& Galván-Guevara, S. (2015). Registro de mortalidad de fauna silvestre por colisión vehicular en la carretera Toluviejo-ciénaga La Caimanera, Sucre, Colombia. Biota Colombiana, 16(1), 67-77.

De la Ossa, J., De la Ossa, V., \& Medina-Bohórquez, E. L. K. I. N. (2015). Atropellamiento de fauna silvestre. Revista Colombiana de Ciencia Animal-RECIA, 7(1), 109-116.

Delgado-Vélez, C. A. (2007). Muerte de mamíferos por vehículos en la vía del Escobero, Envigado (Antioquia), Colombia. Actualidades Biológicas, 29(87), 229-233.

Delgado Vélez, C. A. (2014). Adiciones al atropellamiento vehicular de mamíferos en la vía de El Escobero, Envigado (Antioquia), Colombia. Revista EIA, $11(22), 147-153$.

Dhindsa, M. S., Sandhu, J. S., Sandhu, P. S., \& Toor, H. S. (1988). Roadside birds in Punjab (India): Relation to mortality from vehicles. Environmental Conservation, 15, 303-310.

Diaz-Pulido, A., \& Benítez, A. (2013). Wildlife road crossing and mortality: Lessons for wildlife friendly road design in Colombia. Proceeding of International Conference on Ecology and Transportation, 2-18.

Dougherty, R. R. (2015). Hotspot Analysis of Wildlife Vehicle Collisions of BR-262, Mato Grosso Do Sul, Brazil and Recommendations for Mitigation Efforts (Doctoral dissertation). Florida Atlantic University, USA.

Drews, C. (1995). Road kills of animals by public traffic in Micumi National Park, Tanzania, with notes on baboon mortality. African Journal of Ecology, 33, 89-100.

Eloy Seijas, A., Araujo-Quintero, A., \& Velásquez, N (2013). Mortalidad de vertebrados en la carretera Guanare-Guanarito, estado Portuguesa, Venezuela. Revista de Biología Tropical, 61(4), 1619-1636. doi: 10.15517/rbt.v61i4.12803

Fahrig, L., \& Rytwinski, T. (2009). Effects of roads on animal abundance: an empirical review and synthesis. Ecology and Society, 14(1), 21. doi:10.5751/ES-02815-140121.

Ferreira da Cunha, H., Alves Moreira, F. G., \& Sousa Silva, S. D. (2010). Road kill of wild vertebrates along the GO-060 road between Goiânia and Iporá, Goiás State, Brazil. Acta Scientiarum. Biological Sciences, 32(3), 257-263.

Figueroa, C. J. P., Ruíz, R. D. C. L., Guadarrama, E. M., Leal, J. D. D. V., Méndez, J. S., Zayas, E. E. M., ... \& Ruíz, F. S. Z. (2014). Un asesino a sueldo: el impacto de las carreteras en la fauna silvestre. Kuxulkab', 20(38), 23-28.

Freitas, S. R., Sousa, C. O., \& Bueno, C. (2013). Effects of landscape characteristics on road kill of mammals, birds and reptiles in a highway crossing the Atlantic Forest in southeastern Brazil. Proceedings of the International Conference on Ecology and Transportation, 1-11.

Glista, D. J., DeVault, T. L., \& DeWoody, J. A. (2009). A review of mitigation measures for reducing wildlife mortality on roadways. Landscape and urban planning, 91(1), 1-7. doi:10.1016/j. landurbplan.2008.11.001

González-Gallina, A., Benítez-Badillo, G., Hidalgo-Mihart, M. G., Equihua, M., \& Rojas-Soto, O. R. (2015). Road kills as a complementary information source for biological surveys using rodents as a model. Journal of Mammalogy, 20(10), 1-10

González, A., \& Badillo, G. B. (2013). Road ecology studies for Mexico: A review. Oecologia Australis, 17(1), 175-190.

Goosem, M. (2007). Fragmentation impacts caused by roads through rainforests. Current Science, 93(11), $1587-1595$;

Goosem, M., Wilson, R., Weston, N., \& Cohen, M. (2008). Highway overpass evaluation of effectiveness: Upgrade Project. Cairns, Australia: James Cook University.

Guimarães, T. (2015). A principal causa da morte de animais silvestres no Brasil. London: British Broadcasting Corporation. Retrieved from http://www.bbc.com/portuguese/ noticias/2015/10/150924_atropelamentos_fauna_tg

Gumier-Costa, F., \& Sperber, C. F. (2009). Atropelamentos de vertebrados na Floresta Nacional de Carajás, Pará, Brasil. Acta Amazonica, 39(2), 459-466. doi: 10.1590/S0044-59672009000200027

Huijser, M. P., Abra, F. D., \& Duffield, J. W. (2013). Mammal road mortality and cost-benefit analyses of mitigation measures aimed at reducing collisions with capybara (Hydrochoerus hydrochaeris) in São Paulo State, Brazil. Oecologia Australis, 17(1), 129-146. 
Karunarathna, S., Ranwala, S., Surasinghe, T., \& Madawala, M. (2017). Impact of vehicular traffic on vertebrate fauna in Horton plains and Yala national parks of Sri Lanka: some implications for conservation and management. Journal of Threatened Taxa, 9(3), 9928-9939. doi:10.11609/jott.2715.9.3.9928-9939

Kioko, J., Kiffner, C., Jenkins, N., \& Collinson, W. J. (2015). Wildlife road kill patterns on a major highway in northern Tanzania. African Zoology, 50(1), 17-22. doi:10.1080/15627020.2015.1021161

Kiros, W., Kibrom, F., Raman, P. V., Teferi, M., Solomon, K., \& Meheretu, Y. (2016). Vehicle-wild vertebrate collision mortality on the highways of Tigray, Ethiopia, implications for conservation. African Journal of Ecology, 54(4), 442-449. doi:10.1111/aje.12325

Knutson, R. (1986). Flattened Fauna: A Field Guide to Common Animals of Roads, Streets and Highways. Berkeley, California: Ten Speed Press.

Kroll, G. (2015). “An Environmental History of Roadkill: Road Ecology and the Making of the Permeable Highway," Environmental History, 20, 4-28.

Kumara, H. N., Sharma, A. K., Kumar, A., \& Singh, M. (2000). Road kills of wild fauna in Indira Gandhi Wildlife Sanctuary, Western Ghats, India: implications for management. Biology Conservation, 3, 41-47.

La Ossa-Nadjar, D., \& De La Ossa, V. (2015). Vehicle collisions with wild fauna on the two roads that pass through the Montes de María, Sucre, Colombia. Revista UDCA Actualidad \& Divulgación Científica, 18(2), 503-511.

Laurance, W. F., Goosem, M., \& Laurance, S. G. (2009). Impacts of roads and linear clearings on tropical forests. Trends in Ecology \& Evolution, 24(12), 659669. doi: 10.1016/j.tree.2009.06.009

Laurian, C., Dussault, C., Ouellet, J. P., Courtois, R., Poulin, M., \& Breto, L. (2008). Behavior of Moose Relative to a Road Network. Journal of Wildlife Management, 72(7), 1550-1557. doi: 10.2193/2008-063

López-Herrera, D. F., León-Yusti, M., Guevara-Molina, S C., \& Vargas-Salinas, F. (2016). Reptiles in biological corridors and road kills in Barbas-Bremen, Quindío, Colombia. Revista de la Academia Colombiana de Ciencias Exactas, Físicas y Naturales, 40(156), 484493. doi:10.18257/raccefyn.334

Machado, F. S., Fontes, M. A., Moura, A. S., Mendes, P. B., \& Romao, B. D. S. (2015). Road kill on vertebrates in Brazil: seasonal variation and road type comparison. North-Western Journal of Zoology, 11(2), 247-252.

McLennan, M. R., \& Asiimwe, C. (2016). Cars kill chimpanzees: case report of a wild chimpanzee killed on a road at Bulindi, Uganda. Primates, 57(3), 377-388. doi:10.1007/s10329-016-0528-0
Medrano, V. P. M. (2015). Efecto de las carreteras en la mortalidad de vertebrados en un área megadiversa: Los Andes Tropicales del Ecuador (Master's thesis). PUCE, Ecuador.

Monge-Nájera, J. (1996). Vertebrate mortality on tropical highways: the Costa Rican case. Mortalidad de vertebrados en las carreteras tropicales: el caso de Costa Rica. Vida Silvestre Neotropical, 5(2), 154-156.

Motley, J. L., Stamps, B. W., Mitchell, C. A., Thompson, A. T., Cross, J., You, J., Powell, D.R., Stevenson, B. S. \& Cichewicz, R. H. (2016). Opportunistic sampling of roadkill as an entry point to accessing natural products assembled by bacteria associated with nonanthropoidal mammalian microbiomes. Journal of Natural Products, 80(3), 598-608.

Nadjar, O. D. O., \& De La Ossa, J. (2013). Fauna silvestre atropellada en dos vías principales que rodean los Montes de María, Sucre, Colombia. Revista Colombiana de Ciencia Animal-RECIA, 5(1), 158-164.

Nagar, P., Meena, S. M., \& Dube, P. (2013). Mortality data of reptilian fauna due to vehicular traffic in south eastern Rajasthan, India. Bioscience Biotechnology Research Communications, 6(2), 196-198.

Parry, A. (2007). Roadkill artist speaks of controversial work. Stroud News and Journal (Gloucestershire). Retrieved from: https://goo.gl/yUsrMN

Peterson, B. (1987). The Original Road Kill Cookbook. Berkeley, California: Ten Speed Press.

Pinowski, J. (2005). Road kills of vertebrates in Venezuela. Revista Brasileira de Zoologia, 22(1), 191-196. doi:10.1590/S0101-81752005000100023

Pragatheesh, A., \& Rajvanshi, A. (2013). Spatial patterns and factors influencing the mortality of snakes on the national highway-7 along Pench Tiger reserve, Madhya Pradesh, India. Oecologia Australis, 17(1), 20-35.

Quintero-Ángel, A., Osorio-Dominguez, D., Vargas-Salinas, F., \& Saavedra-Rodríguez, C. A. (2012). Road kill rate of snakes in a disturbed landscape of Central Andes of Colombia. Herpetology Notes, 5, 99-105.

Ranta, E., Lundberg, P., \& Kaitala, V. (2006). Ecology of populations. Cambridge: Cambridge University Press.

Rojas-Chacón, E. (2011). Atropello de vertebrados en una carretera secundaria en Costa Rica. Vertebrate roadkills in a secondary road in Costa Rica. Cuadernos de Investigación, 3(1), 81-84. doi:10.22458/urj.v3i1.209

Samson, A., Ramakrishnan, B., Veeramani, A., Santhoshkumar, P., Karthick, S., Sivasubramanian, G., ... \& Ravi, P. (2016). Effect of vehicular traffic on wild animals in Sigur Plateau, Tamil Nadu, India. Journal 
of Threatened Taxa, 8(9), 9182-9189. doi:10.11609/ jott.1962.8.9.9182-9189

Sanborn, V. (2008). Road Accidents, Regency Style. In Jane Austen's World. Retrieved from https:// janeaustensworld.wordpress.com/2008/03/14/ road-accidents-regency-style/

Sánchez, J. I., Delgado-Trejo, C., Mendoza-Ramírez, E., \& Suazo-Ortuño, I. (2013). Las carreteras como una fuente de mortalidad de fauna silvestre en México. CONABIO Biodiversitas, 11, 12-16.

Santos, A. L. P. G., Rosa, C. A., \& Bager, A. (2012). Variação sazonal da fauna selvagem atropelada na rodovia MG 354, Sul de Minas Gerais - Brasil. Biotemas, 25(1), 73-79.

Santos, R. A. L., Ascensão, F., Ribeiro, M. L., Bager, A., Santos-Reis, M., \& Aguiar, L. M. (2017). Assessing the consistency of hotspot and hot-moment patterns of wildlife road mortality over time. Perspectives in Ecology and Conservation, 15(1), 56-60.

Santos, R. A. L., Santos, S. M., Santos-Reis, M., de Figueiredo, A. P., Bager, A., Aguiar, L. M., \&Ascensão, F. (2016). Carcass persistence and detectability: reducing the uncertainty surrounding wildlife-vehicle collision surveys. PloS one, 11(11), e0165608.

Schulz, K. F., Chalmers, I., Hayes, R. J., \& Altman, D. G. (1995). Dimensions of Methodological Quality Associated With Estimates of Treatment Effects in Controlled Trials. Journal of the American Medical Association, 273(5), 408-412, doi:10.1001/ jama.1995.03520290060030

Schutt, P. (2008). Analysis of Road Kill Data from Ankarafantsika National Park, Madagascar (Masther thesis). Duke University, North Carolina, USA.

Secco, H., Ratton, P., Castro, E., Lucas, P. S., \& Bager, A. (2014). Intentional snake road-kill: a case study using fake snakes on a Brazilian road. Tropical Conservation Science, 7(3), 561-571.

Selvan, K. M., Sridharan, N., \& John, S. (2012). Road kill animals on national highways of Karnataka, India.
Journal of Ecology and the Natural Environment, 4(14), 363-365. doi: 10.5897/JENE11.068

Solanki, D., Beleem, I., Kanejiya, J., \& Gohil, B. (2017). A study on animal-vehicle collision in Bhavnagar city and nearby area, Gujarat, India. Journal of Entomology and Zoology Studies, 5(1), 622-625.

Sosa, R., \& Schalk, C. M. (2016). Seasonal Activity and Species Habitat Guilds Influence Road-Kill Patterns of Neotropical Snakes. Tropical Conservation Science, 9(4), 1-12. doi: 10.1177/1940082916679662

Spellerberg, I. A. N. (1998). Ecological effects of roads and traffic: a literature review. Global Ecology and Biogeography, 7(5), 317-333. doi: 10.2307/2997681

Taylor, B. D., \& Goldingay, R. L. (2004). Wildlife roadkills on three major roads in north-eastern New South Wales. Wildlife Research, 31(1), 83-91. doi: 10.1071/ WR01110

Teixeira, F. Z., Coelho, A. V. P., Esperandio, I. B., \& Kindel, A. (2013). Vertebrate road mortality estimates: effects of sampling methods and carcass removal. Biological Conservation, 157, 317-323.

Teixeira, F., Coelho, I., Esperandio, I., Oliveira, N., Porto, F., Dornelles, S., ... \& Kindel, A. (2013). Are roadkill hotspots coincident among different vertebrate groups? Oecologia Australis, 17(1), 36-47.

Trombulak, S. C., \& Frissell, C. A. (2000). Review of ecological effects of roads on terrestrial and aquatic communities. Conservation Biology, 14(1), 18-30. doi:10.1046/j.1523-1739.2000.99084.x

Vargas-Salinas, F., \& López-Aranda, F. (2012). Las Carreteras Pueden Restringir El Movimiento De Pequeños Mamíferos En Bosques Andinos De Colombia? Estudio De Caso En El Bosque De Yotoco, Valle Del Cauca. Caldasia, 34(2), 409-420.

Vijayakumar, S. P., Vasudevan, K., \& Ishwar, N. M. (2001). Herpetofaunal mortality on roads in the Anamalai Hills, southern Western Ghats. Hamadryad-Madras, 26, 253-260. 


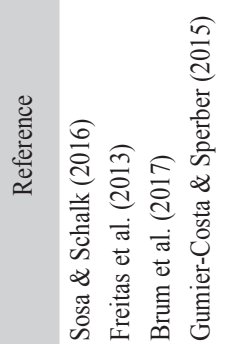

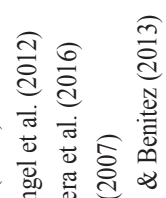

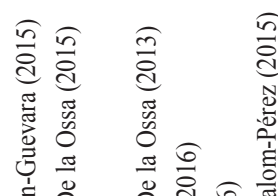

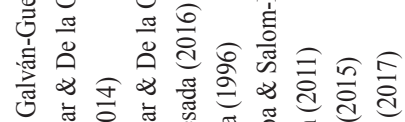

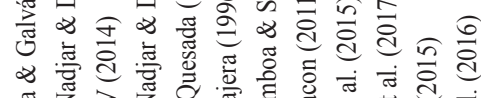

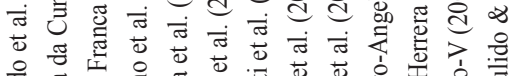

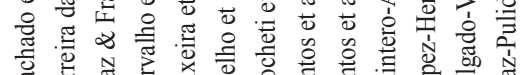

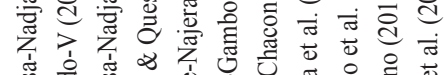

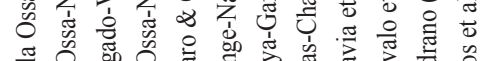

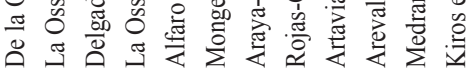

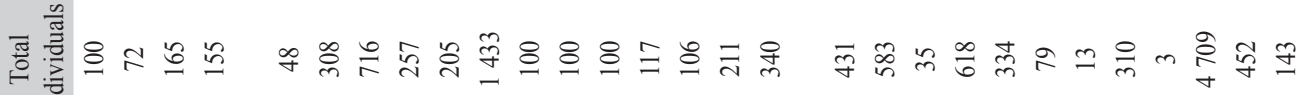

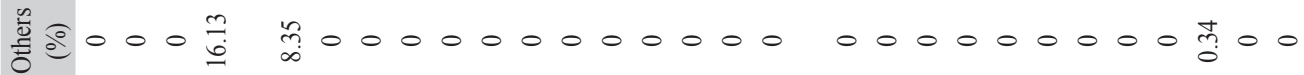

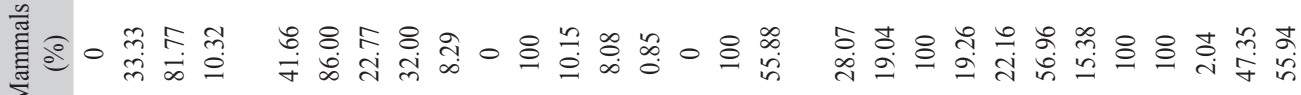

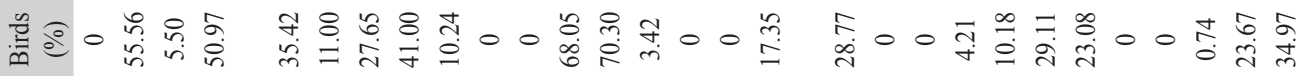

层 产 育

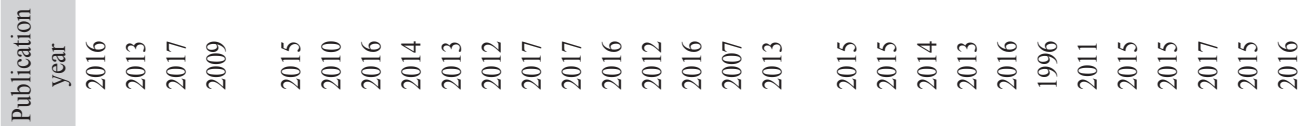
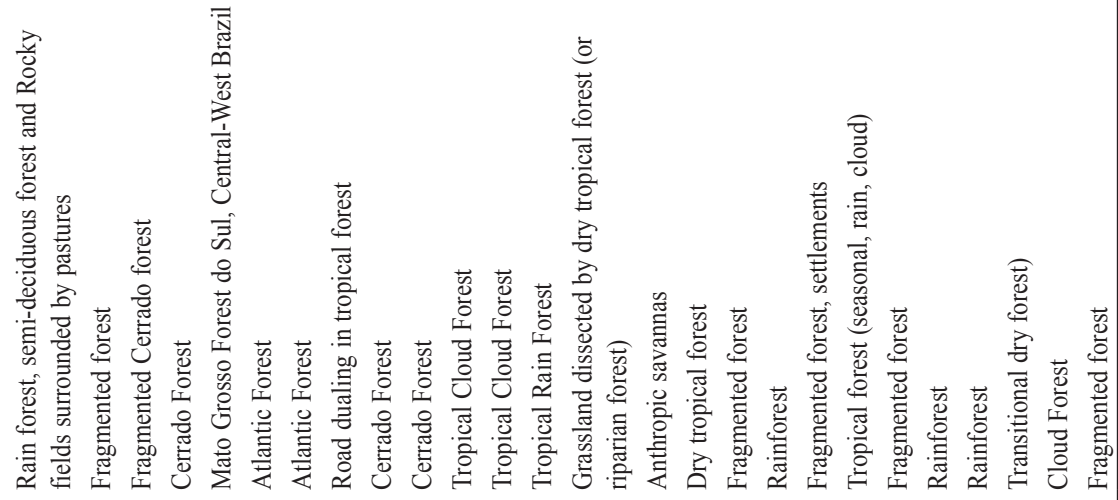


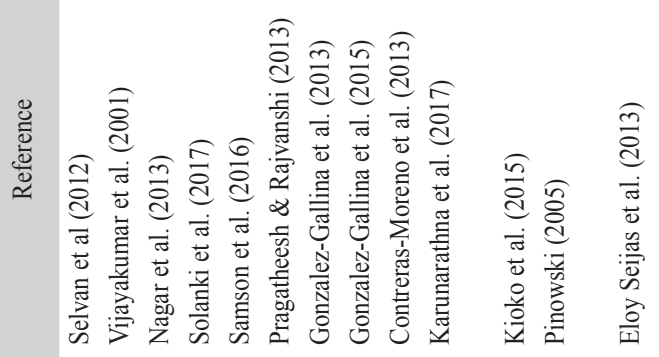

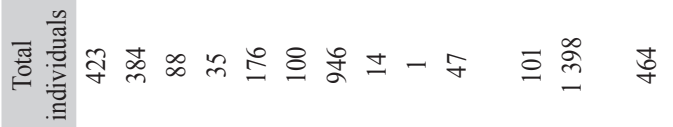

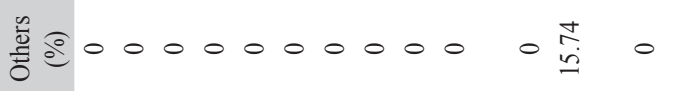

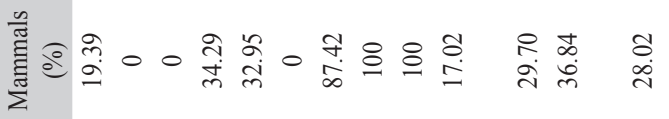

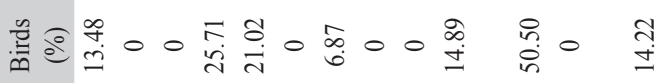

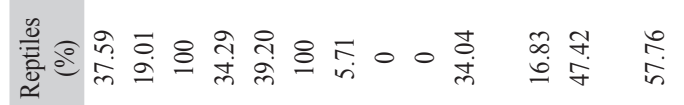

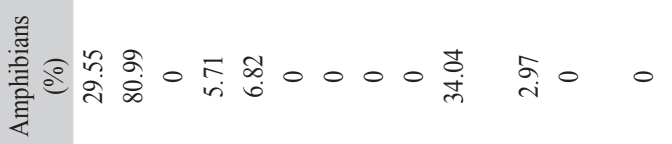

产券

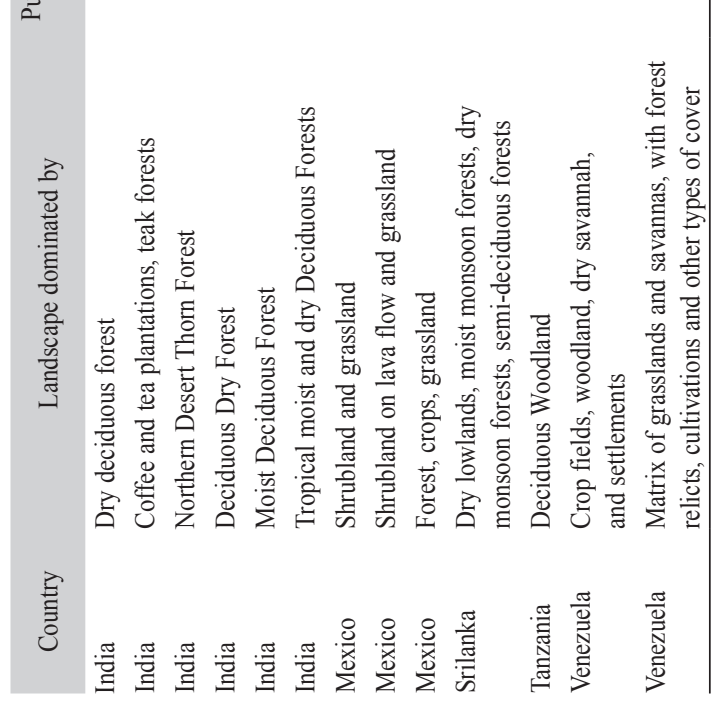

